\title{
The Impact of Progesterone Receptor Expression on Platinum Sensitivity and Survival Outcomes in Patients With Ovarian Clear Cell Carcinoma
}

\section{Chen-Hsuan Wu}

Kaohsiung Medical Center: Chang Gung Memorial Hospital Kaohsiung Branch

Hung-Chun Fu

Kaohsiung Medical Center: Chang Gung Memorial Hospital Kaohsiung Branch

\section{Yu-Che Ou}

Chiayi Chang Gung Memorial Hospital

Jui Lan

Kaohsiung Medical Center: Chang Gung Memorial Hospital Kaohsiung Branch

Hao Lin ( $\sim$ haolin423700@gmail.com )

Kaohsiung Medical Center: Chang Gung Memorial Hospital Kaohsiung Branch https://orcid.org/00000003-0828-6763

\section{Research Article}

Keywords: Ovarian clear cell carcinoma, Progesterone receptor, Platinum sensitivity

Posted Date: July 9th, 2021

DOl: https://doi.org/10.21203/rs.3.rs-683804/v1

License: (9) (1) This work is licensed under a Creative Commons Attribution 4.0 International License. Read Full License 


\section{Abstract}

\section{Background}

Ovarian clear cell carcinoma (OCCC) is considered to be a relatively platinum-resistant malignancy. In the present study, we investigated the impact of progesterone receptor (PR) expression on platinum sensitivity and survival outcomes in patients with OCCC.

\section{Methods}

We retrospectively reviewed 80 patients with OCCC who underwent surgery followed by adjuvant chemotherapy, and analyzed PR expression by immunohistochemical staining. The PR expression was quantified using the $\mathrm{H}$-score. The platinum sensitivity and survival outcomes were compared between those with a weak and strong PR expression. Cisplatin viability experiments were performed in OCCC cell lines (TOV-21G) with different PR expressions.

\section{Results}

Among the 80 patients, 66 and 14 were considered to have platinum-sensitive and platinum-resistant disease, respectively. The mean PR H-score of the platinum-sensitive tumors was significant higher than that of the platinum-resistant tumors $(p=0.002)$. Although there were no significant differences in progression-free and overall survival between the patients with high and low PR expressions, the patients with a high PR expression had a trend towards better survival. In cell models, PR protein was weakly detectable in TOV-21G cells. Through transfection of PR gene, TOV-21G cells were shown to have a strong PR expression by Western blot analysis. After treating the TOV-21G cells with cisplatin, we found that the overexpression of PR enhanced cisplatin cytotoxicity.

\section{Conclusions}

The patients in this study with a strong PR expression were associated with better platinum sensitivity and survival, and this was compatible with our experimental findings. The value of PR as a tumor sensitizer to cisplatin in OCCC should be further investigated.

\section{Background}

In the United States, approximately 22,530 patients were newly diagnosed with ovarian cancer and approximately 13,980 patients died from this disease in 2016 , representing the fifth leading cause of cancer-related deaths in women [1]. According to the Taiwan Cancer Registry, there were 1,507 newly diagnosed ovarian cancer patients and 656 deaths in Taiwan in 2016, representing the seventh leading cause of cancer-related deaths in women.

Most ovarian malignancies are epithelial ovarian cancer (EOC), however differences in the incidence of EOC subtypes have been reported in different areas. Ovarian clear cell carcinoma (OCCC) is unique at 
cellular and molecular levels. Endometriosis is a precancerous lesion that has been associated with a 3fold increased risk of OCCC, and the incidence of OCCC ranges from 13-28\% in Asia, which is much higher than in Western countries (5-10\%) [2-5]. According to a report from the Taiwan Cancer Registry, OCCC accounted for 14-18\% of all cases of EOC from 2012-2016. OCCC is more commonly detected at an early stage and has a good prognosis. However, it is considered to be platinum resistant in the advanced stage, and the prognosis is worse than high-grade serous carcinoma [6-9]. Therefore, novel treatments are urgently needed, and many molecular targeted therapies and immunotherapies are currently being studied.

The presence of sex steroid hormone receptors in EOC tissue suggests that hormones may play a role in the origin and promotion of this disease [10]. Epidemiological evidence strongly suggests that progesterone-containing contraceptives and pregnancy appear to provide a protective effect against EOC, indicating that progesterone receptor (PR) may play a role in predicting the prognosis [11]. Although previous studies have reported an association between a strong PR expression and improved diseasespecific survival in patients with ovarian high-grade serous and endometrioid cancer, the results in OCCC have been conflicting due to limited sample sizes and statistical power $[12,13]$. However, differential expressions of PR from atypical endometriosis to OCCC have been reported, suggesting its role in predicting prognosis $[14,15]$. As the association between PR status and chemosensitivity has not been investigated before, the aim of this study was to evaluate the associations among PR expression, platinum sensitivity, and survival in OCCC patients and cell line models.

\section{Materials And Methods}

\section{Patients}

We retrospectively reviewed patients with OCCC between January 2008 and December 2016 in Kaohsiung Chang Gung Memorial Hospital who underwent primary surgery followed by more than 4 courses of adjuvant chemotherapy. The stages were assigned according to the International Federation of Gynecology and Obstetrics (FIGO) 2014 system. The study cases were selected based on the availability of tissue for immunohistochemical (IHC) staining. Patients were excluded if sufficient tissue samples were not available, they had not undergone chemotherapy or received fewer than 4 courses of chemotherapy, did not have regular follow-up data, or had double cancers. Clinical data including demographics, FIGO stage, carbohydrate antigen-125 (CA-125) level, concurrent endometriosis (defined as endometriosis presenting at the same site of cancer), platinum sensitivity, PR expression, and survival time were collected from clinical records. Platinum sensitivity was classified as being either resistant or sensitive according to the time of relapse ( 6 months as the cut-off) since finishing first-line chemotherapy. Clinical parameters including PR expression were compared between the platinumsensitive and platinum-resistant groups. The study protocols were approved by the Institutional Review Board of Chang Gung Memorial Hospital (approval number: 201601487B0C503).

Immunohistochemistry analysis 
Paraffin-embedded ovarian tissues were sliced into 3- $\mu$ m-thick sections, deparaffinized in xylene, and rehydrated through an alcohol gradient. Activity of endogenous peroxide was blocked with $3 \% \mathrm{H} 2 \mathrm{O} 2$ for $15 \mathrm{~min}$. The slides were then treated with $1 \mathrm{x}$ citrate buffer pH 6.0 (SIGMA, C9999) for $17 \mathrm{~min}$ in a microwave oven for antigen retrieval, and then incubated with the primary PR antibody (1:200, ThermoFisher, MA1-411) at $4^{\circ} \mathrm{C}$ overnight, which can detect both the A and B form of PR. IHC staining was performed using an UltraVision Quanto Detection System HRP kit (ThermoFisher, TL-060-QHL) and DAB Quanto reagent (ThermoFisher, TA-125-QHDX) according to the manufacturer's instructions. Finally, the sections were counterstained with hematoxylin and mounted with aqueous mounting media. The slides were visualized at 200X magnification, and PR staining was scored using the H-score method (range 0-300) obtained by multiplying the tumor nuclei cell intensity (on a scale of 0 to 3 ) by the percentage of positive tumor nuclei cells (on a scale of 0 to 100) [16]. One pathologist (Lan J) blindly scored all of the cases.

PR-overexpressing ovarian cancer cell lines

The plasmids pcDNA3-hPR-A (Cat.No.\#89119) and pcDNA3-PRB (Cat.No.\#89130) were purchased from Addgene. TOV21 $\mathrm{G}$ cells were seeded in a 6 -well plate at $3 \times 10^{5}$ cells per well for $24 \mathrm{~h}$, and transfection was carried out using Lipofectamine 2000 reagent (Invitrogen, Cat.No.\#11668019) according to the manufacturer's instructions. After transfection for $48 \mathrm{~h}$, the cells were harvested for Western blot and cell viability analyses.

Cell viability assay

PR-overexpressing cells were seeded in a 96-well plate at 5000 cells per well, and incubated at $37^{\circ} \mathrm{C}$ overnight before drug treatment. The cells were treated with different concentrations of cisplatin for $24 \mathrm{~h}$, 48 h, 72 h, and 96 h. PrestoBlue Cell Viability Reagent (10:1) (Invitrogen, A13261) was then added and allowed to incubate at $37^{\circ} \mathrm{C}$ for $2-3 \mathrm{~h}$. The absorbance at a wavelength of $570-600 \mathrm{~nm}$ was measured using a SpectraMax ABS Absorbance Microplate Reader (Molecular Devices). The viability of cells was expressed as a percentage of absorbance in treated wells relative to that in untreated (control) wells.

Western blot analysis

Cell proteins were lysed in PRO-PREP Protein Extraction Solution (iNtRON, Cat.No.\#17081.1), and the proteins of the lysates were quantified with a BCA Protein Assay kit (Merck Millipore, 71285-3). After the proteins had been separated by $8 \%-10 \%$ SDS-PAGE and transferred onto PVDF membranes (Merck Millipore, IPVH00010), the membranes were blocked with 5\% non-fat milk in Tris Buffered Saline (SIGMA, T5912) containing $0.1 \%$ Tween-20 for 30 min at room temperature, and probed with specific primary antibodies against PR (1:2000, ThermoFisher, MA1-411) and $\beta$-actin (1:10000, Merck Millipore, A5441) at $4^{\circ} \mathrm{C}$ overnight. The secondary antibody was conjugated with horseradish peroxidase (HRP) (1:8000, Merck Millipore, A9044) for $90 \mathrm{~min}$ at room temperature. Immunoreactive bands were visualized using Immobilon Western Chemiluminescent HRP Substrate (Merck Millipore, WBKLS0500) and exposed to Xray film for autoradiography. 


\section{Statistical analysis}

Receiver operating characteristic (ROC) curve analysis was used to identify optimal cut-off values of PR $\mathrm{H}$-score to predict platinum sensitivity and survival. Progression-free survival (PFS) and overall survival (OS) were defined as the interval from the date of diagnosis to the first evidence of progression and death, respectively. Comparisons of median and mean values were performed using the two-sample $t$ test. Frequency distributions between categorical variables were compared using the chi-square or Fisher's exact test. Multivariate Cox proportional hazards analysis was used to identify the most significant independent prognostic factors for PFS and OS. Actuarial rates of survival were estimated with the Kaplan-Meier method, and statistical differences between groups were examined using the log rank test. The Student's t-test was used to assess statistical significance between the control and PRA/PR-B treatment groups and the PrestoBlue assay was used to assess differences between control and PR-A/PR-B groups in the difference concentration of cisplatin treatment using the cell line TOV-21G. Data management and analysis was performed using SPSS software for Windows version 22 (IBM, Armonk, NY, USA). A $p$ value less than 0.05 was considered to indicate statistical significance.

\section{Results}

Clinical data

A total of 592 ovarian cancer patients were identified during the study period. We excluded 481 patients who had a non-OCCC histology, 15 patients who did not undergo chemotherapy or had received fewer than 4 courses of chemotherapy, 9 patients due to insufficient tissue samples for IHC staining, and 7 patients with inadequate follow-up data or double cancers. Finally 80 patients met the eligibility criteria and constituted the study cohort. The mean age at diagnosis was 48.9 years (range, 28-61 years), and the median follow-up time was 50 months (range, 5-132 months). The basic characteristics of the patients are listed in Table 1. Among the 80 patients, 66 and 14 cases were defined as having platinumsensitive and platinum-resistant disease, respectively. The platinum-sensitive patients were significantly associated with a higher rate of concurrent endometriosis and higher mean PR H-score (Table 2). Positive PR staining (H-score > 1) was noted in 30 patients (37.5\%). Based on the ROC curve analysis, the optimal cut-off value of PR H-score to predict platinum sensitivity and survival was 50 (area under the curve 0.64 , 95\% [confidence interval] Cl: $0.51-0.77)$. An H-score of 50 or higher was defined as a strong PR expression (13 patients), and an $\mathrm{H}$-score lower than 50 as a weak PR expression (67 patients). There were no significant differences in the distribution of clinicopathological variables between the weak and strong PR expression groups (Table 3). Typical examples of IHC staining of PR are shown in Fig. 1. Univariate analysis demonstrated significantly better 5-year PFS and OS for the patients with early FIGO stage (I/II), concurrent endometriosis, and pretreatment CA125 level lower than $35 \mathrm{U} / \mathrm{mL}$, while only trends were noted in the strong PR expression group. Multivariate Cox regression analysis showed that only advanced FIGO stage was significantly associated with worse PFS (hazard ratio [HR] 2.427; 95\% Cl 1.004-5.869) and OS (HR 3.22; 95\% Cl 1.27-8.161) (Table 4). Because FIGO stage was the only independent factor predicting survival, we further investigated the correlation between PR expression and FIGO stage. We 
found a stepwise decrease in PR expression from FIGO stage I to IV, although without significance (Table 3). 
Table 1

Clinicopathological characteristics of all patients $(\mathrm{N}=80)$

\begin{tabular}{|c|c|}
\hline Age, mean (SD) & $48.9(10)$ \\
\hline Follow-up, months, median (range) & $50(5-132)$ \\
\hline FIGO stage, n (\%) & $44(55)$ \\
\hline I & $12(15)$ \\
\hline ॥ & $20(25)$ \\
\hline III & $4(5)$ \\
\hline \multicolumn{2}{|l|}{ IV } \\
\hline Menopause, n (\%) & $41(51.2)$ \\
\hline Yes & $39(48.8)$ \\
\hline \multicolumn{2}{|l|}{ No } \\
\hline Parity, n (\%) & $31(38.8)$ \\
\hline Nulliparous & $49(61.2)$ \\
\hline \multicolumn{2}{|l|}{$\geq 1$} \\
\hline Pretreatment CA125, n (\%) & $11(13.8)$ \\
\hline$<35 \mathrm{U} / \mathrm{mL}$ & $59(73.8)$ \\
\hline \multicolumn{2}{|l|}{$\geq 35 \mathrm{U} / \mathrm{mL}$} \\
\hline Concurrent endometriosis, n (\%) & $19(23.8)$ \\
\hline Yes & $61(76.2)$ \\
\hline \multicolumn{2}{|l|}{ No } \\
\hline PR expression, n (\%) & $30(37.5)$ \\
\hline Yes & $50(62.5)$ \\
\hline \multicolumn{2}{|l|}{ No } \\
\hline PR H-score, mean (SD) & $18.95(34.73)$ \\
\hline Platinum sensitivity, n (\%) & $66(82.5)$ \\
\hline Sensitive & $14(17.5)$ \\
\hline Resistant & \\
\hline
\end{tabular}


Table 2

Factors associated with platinum sensitivity in the patients with ovarian clear cell carcinoma

\begin{tabular}{|llll|}
\hline Factors & Platinum-sensitive & Platinum-resistant & Pvalue \\
& $\mathbf{n}=66$ & $\mathbf{n = 1 4}$ & \\
\hline Age (mean), years & 48.3 & 51.7 & 0.441 \\
\hline Menopause, n (\%) & $32(48.5)$ & $9(64.3)$ & 0.283 \\
\hline Parity $\geq 1, \mathrm{n}(\%)$ & $41(62.1)$ & $8(57.1)$ & 0.728 \\
\hline $\begin{array}{l}\text { Concurrent } \\
\text { endometriosis, } \mathrm{n}(\%)\end{array}$ & $19(28.8)$ & $0(0)$ & 0.033 \\
\hline $\begin{array}{l}\text { Pretreatment CA125 } \\
\text { (mean), U/mL }\end{array}$ & 537 & 709 & 0.825 \\
\hline PR positive, $\mathrm{n}(\%)$ & $29(43.9)$ & $4(28.6)$ & 0.376 \\
\hline PR H-score (mean) & 21.9 & 5 & 0.002 \\
\hline PR H-score $\geq 50, \mathrm{n}(\%)$ & $13(19.7)$ & $0(0)$ & 0.110 \\
\hline PR Progesterone receptor & & \\
\hline
\end{tabular}

Table 3

Factors associated with PR expression in the patients with OCCC

\begin{tabular}{|c|c|c|c|}
\hline Factors & PR $^{\text {weak }}(n=67)$ & PR $^{\text {strong }}(n=13)$ & $p$ value \\
\hline Age (mean) & 49.49 & 45.85 & 0.975 \\
\hline Menopause, n (\%) & $35(52.2)$ & $6(46.2)$ & 0.688 \\
\hline Parity $\geq 1, \mathrm{n}(\%)$ & $42(62.7)$ & $7(53.8)$ & 0.549 \\
\hline \multicolumn{3}{|l|}{ FIGO stage } & \multirow[t]{2}{*}{0.588} \\
\hline I $(\mathrm{n}=44)(\%$ within stage $)$ & $35(79.5)$ & $9(20.5)$ & \\
\hline II ( $n=12)$ (\% within stage) & $10(83.3)$ & $2(16.7)$ & \\
\hline III $(\mathrm{n}=20)(\%$ within stage $)$ & $18(90.0)$ & $2(10.0)$ & \\
\hline IV $(n=4)$ (\% within stage) & $4(100)$ & $0(0.0)$ & \\
\hline Concurrent endometriosis, $\mathrm{n}(\%)$ & $17(25.4)$ & $2(15.4)$ & 0.439 \\
\hline Pretreatment CA125 (mean) & 573.7 & 532.2 & 0.324 \\
\hline $\begin{array}{l}C A \text { Carbohydrate antigen; } F / G O I \\
\text { Progesterone receptor; } P R^{\text {weak }} \mathrm{PP}\end{array}$ & $\begin{array}{l}\text { I Federation of } \\
\text { 50; } P R^{\text {strong }} \text { PR }\end{array}$ & $\begin{array}{l}\text { logy and Obstetr } \\
\geq 50\end{array}$ & \\
\hline
\end{tabular}


Table 4

Multivariate Cox regression analyses of progression-free and overall survival

\begin{tabular}{|c|c|c|c|c|c|c|}
\hline & PFS & & & os & & \\
\hline Factors & $\mathrm{HR}$ & $95 \% \mathrm{Cl}$ & $P$ value & $H R$ & $95 \% \mathrm{Cl}$ & $P$ value \\
\hline Menopause & 1.324 & $0.515-3.403$ & 0.560 & 1.940 & $0.707-5.318$ & 0.198 \\
\hline $\begin{array}{l}\text { Parity } \\
(\geq 1 \text { vs. } 0)\end{array}$ & 0.856 & $0.336-2.180$ & 0.745 & 1.061 & $0.386-2.920$ & 0.908 \\
\hline $\begin{array}{l}\text { Concurrent endometriosis } \\
\text { (yes vs. no) }\end{array}$ & 0.141 & $0.018-1.084$ & 0.060 & 0.187 & $0.024-1.464$ & 0.110 \\
\hline $\begin{array}{l}\text { CA125 } \\
(\geq 35 \text { vs. }<35)\end{array}$ & 3.252 & $0.409-25.89$ & 0.265 & 4.767 & $0.588-38.65$ & 0.144 \\
\hline $\begin{array}{l}\text { PR H-score } \\
(\geq 50 \text { vs. }<50)\end{array}$ & 0.369 & $0.085-1.594$ & 0.182 & 0.311 & $0.070-1.391$ & 0.126 \\
\hline $\begin{array}{l}\text { FIGO stage } \\
\text { (III/IV vs. I/II) }\end{array}$ & 2.427 & $1.004-5.869$ & 0.049 & 3.220 & $1.27-8.161$ & 0.014 \\
\hline $\begin{array}{l}\text { CA Carbohydrate antigen; } \\
\text { Obstetrics; HR Hazard ratio } \\
\text { receptor }\end{array}$ & $\begin{array}{l}\text { nfider } \\
\text { Overa }\end{array}$ & $\begin{array}{l}\text { interval; FIGO } \\
\text { urvival; PFSP }\end{array}$ & $\begin{array}{l}\text { ernation } \\
\text { ession- }\end{array}$ & $\begin{array}{l}\text { Fede } \\
\text { e sur }\end{array}$ & $\begin{array}{l}\text { on of Gynecol } \\
\text { al; PRProgest }\end{array}$ & $\begin{array}{l}\text { and } \\
\text { he }\end{array}$ \\
\hline
\end{tabular}

Cell line data

The OCCC cell line TOV-21G was obtained from the American Type Culture Collection (Manassas, VA). According to a previous report, the TOV-21G cell line is highly recommended as a model for OCCC research because of similar molecular and immunologic profiles to typical primary tumors [16]. Staining of PR-A and PR-B was very weak in the TOV-21G cells as shown in Fig. 2A. The TOV-21G cells were transfected with plasmids pcDNA3-PRA and pcDNA3-PRB (TOV-21G-PR-A and TOV-21G-PR-B). After transfection, we selected a stable clone with $\mathrm{G} 418200 \mathrm{ug} / \mathrm{mL}$. Protein was extracted and subjected to Western blot, which showed an approximate 300\% increase in PR-A protein expression in TOV-21G-PR-A compared to TOV-21G cells (Fig. 2A). TOV-21G-PR-B cells also demonstrated a significantly higher level of PR-B protein (210\%) than TOV-21G cells (Fig. 2B). To determine the cytotoxic effects of cisplatin on TOV-21G cells with different PR-A and PR-B expressions, we used a PrestoBlue Cell Viability Assay. We found that compared with the control (TOV-21G) cells, the inhibition of viability by cisplatin was significantly greater in both TOV-21G-PR-A and TOV-21G-PR-BA cells $(p<0.01)$ at 48 and $72 \mathrm{~h}$ (Fig. 2A, 2B).

\section{Discussion}


Our results demonstrated that platinum-sensitive tumors were associated with a stronger PR expression both in clinical specimens and cell line models. However, PR status was not significantly associated with PFS or OS in the patients with OCCC.

Previous studies analyzing the expression rates of sex hormone receptors in patients with OCCC have reported a wide range of PR expressions from $0 \%$ [17] to $60 \%$ [18], with most demonstrating $<10 \%$ positivity [19-22]. The percentage of PR-positive patients in the present study was relatively high at $37.5 \%$. The differences among various studies may be due to differences in the PR antibodies used in IHC staining. The most common commercially available PR antibodies include clone 16 , clone 636 , clone 1A6, clone alpha PR6, and clone 1E2. Although all of these antibodies are thought to be able to recognize both PR-A and PR-B isoforms, a previous study demonstrated that some antibodies failed to detect PR-B in tissue sections when using IHC techniques despite their ability to do so with immunoblot analysis [23]. A possible reason is that some epitopes on PR-B may be masked during heat treatment of formalin-fixed tissue, which results in a certain degree of protein tertiary structural change. Therefore, it is possible that PR expression will not be detected or at least will be underestimated in tissues where PR-B is predominant.

To date, no previous study has evaluated PR expression only in OCCC patients. The largest collaborative study from Sieh et al. reported that PR expression was associated with better high-grade serous and endometrioid carcinoma survival but not mucinous or OCCC [12]. Another meta-analysis of 5685 EOC patients from 28 studies found that PR expression was related to PFS and OS, but that when focusing on studies of serous carcinoma the prognostic role of PR disappeared, which is in contrast to Sieh et al.'s study [13]. This discrepancy may be related to differences in the methodologies of measuring PR and interpreting IHC. For example, we quantified PR status using $\mathrm{H}$-score, which is quite different to Sieh et al. Most previous studies have used a three-tier system: negative, weak, and strong, defined as positive staining in $<1 \%, 1-50 \%$, and $\geq 50 \%$ of tumor cell nuclei, respectively. In the present study, we found a stepwise reduction in PR expression from FIGO stage I to IV. Previous studies have reported different expressions of PR, ranging from $100 \%$ in atypical ovarian endometriosis to $35 \%$ in OCCC, suggesting that a loss of PR may be involved in the etiology and progression of OCCC $[14,15]$. As the critical point of PR level change in relation to chemosensitivity or survival is unknown, we quantified PR status and identified an optimal cut-off value. However, even when using this cut-off value, PR was still not a significant prognosticator. There are some possible explanations for this. First, we enrolled many FIGO stage I/II patients. Early-stage OCCC has an excellent prognosis, and even with recurrence the time to relapse may be more than 6 months after completing chemotherapy. Whether these tumors were actually platinumsensitive remains unclear. Second, although we quantified PR status, the $\mathrm{H}$-score values were not normally distributed. We attempted to stratify the patients by early stage versus advanced stage or with concurrent endometriosis versus without, and we even transformed the values to a certain exponent, however we still failed to overcome this problem. Third, the limited number of study patients after excluding others due to various reasons may also have biased the outcomes. 
PR has two isoforms, $A$ and $B$, and the role of each receptor isoform remains unclear with regards to hormone treatment responsiveness and prognosis. In breast cancer, PR-A-predominant breast tumors are more sensitive to anti-progestin treatment, while PR-B-predominant tumors are associated with advanced disease and poor prognosis [24]. In endometrial cancer, both PR-A and PR-B are associated with less aggressive tumors, however only PR-B predicts a better prognosis [25]. An interesting finding in our study was that the patients with either the A or B PR isoform appeared to be more sensitive to cisplatin, and that the patients with a high total PR expression had a trend towards better survival. The association between hormone receptor status and platinum sensitivity has seldom been investigated in EOC. In one preclinical study using OVCAR-3 cells, Preluso et al. reported that a high PR expression in ovarian cancer cells was associated with decreased PR membrane component-1 (PRMC-1) expression, which in turn increased the effectiveness of cisplatin [26]. The same group later transplanted SKOV-3 cells into nude mice, resulting in the development of an OCCC animal model. They demonstrated that PGRMC1 regulated not only the growth and platinum sensitivity of cultured SKOV-3 cells, but also ovarian tumors derived from these cells [27]. In an endometrial tumor model, they also found that PGRMC1-depleted tumors were more responsive to chemotherapeutic stress compared with PGRMC1-intact control tumors [28]. Taken together, these data support the close relationship between PGRMC-1 expression and chemosensitivity. Given the reported inverse relationship between PGRMC-1 and PR expression [26], our results are consistent with Preluso et al., although further studies investigating the relationship between PGRMC-1 and PR with different expressions of the isoforms are needed.

OCCC is thought to be a platinum-resistant malignant disease. Recent studies have identified specific immune-related molecular profiles such as PD-L1 expression and mismatch repair protein defects in OCCC [29,30], which in turn has led to the development of a novel therapeutic approach focusing on immunotherapy. Although recent phase I/II results of using pembrolizumab were promising [31, 32], the sample size was small and further phase II/III verification is needed. Until then, clinicians still need to identify which patients may really benefit from traditional chemotherapy.

\section{Conclusions}

In conclusion, we demonstrated that tumors with a weak PR expression were associated with greater platinum resistance and probably worse survival both in OCCC patients and cell lines. Ascertaining PR status may allow clinicians to more precisely treat OCCC patients with chemotherapy. Further animal experiments and clinical studies are needed to explore the mechanistic roles of PR in predicting chemosensitivity and disease prognosis in OCCC.

\section{Declarations}

\section{Ethics approval and consent to participate}

Institutional Review Board of Chang Gung Memorial Hospital provided ethical approval for the current study (201601487B0C503). Informed consent for use of retrospective patient case data was waived. All 
the methods were carried out in accordance with relevant guidelines and regulations.

\section{Consent for publication}

Not applicable

\section{Availability of data and materials}

The datasets used and/or analysed during the current study are available from the corresponding author on reasonable request.

\section{Competing Interests}

All authors have no conflicts of interest that could be perceived to bias their work, making known all financial support and any other personal connections.

\section{Funding}

The study was funded by Chang Gung Memorial Hospital (CMRPG8H1121).

\section{Authors' contributions}

C.H.W., H.L. designed the study, analyzed the data and helped write the manuscript. J.L. performed the immunohistochemical experiments and analyzed the data. C.H.W., H.C.F. performed statistical analysis. C.H.W. H.C.F. was involved in performing the experiments. Y.C.O., C.H.W., H.L., and H.C.F. provided the clinical resources and executed of the study. C.H.W., H.L. supervised the study and drafted the manuscript. All authors have reviewed and approved the final manuscript.

\section{Acknowledgements}

We thank Chang Gung Medical Foundation Kaohsiung Chang Gung Memorial Hospital Tissue Bank Core Lab and Biobank (CLRPG8I0032) for their excellent technical support, and the Biostatistics Center, and Kaohsiung Chang Gung Memorial Hospital for assistance with the statistical analysis in this study.

\section{References}

1. Siegel RL, Miller KD, Jemal A. Cancer statistics. 2019. CA Cancer J Clin. 2019 Jan;69(1):7-34. https://doi.org/10.3322/caac.21551.

2. Yoshikawa H, Jimbo H, Okada S, Matsumoto K, Onda T, Yasugi T, Taketani Y. Prevalence of endometriosis in ovarian cancer. Gynecol Obstet Invest. 2000;50(Suppl 1):11-7. https://doi.org/10.1159/000052873.

3. Sugiyama T, Okamoto A, Enomoto T, Hamano T, Aotani E, Terao Y, Suzuki N, Mikami M, Yaegashi N, Kato K, Yoshikawa H, Yokoyama Y, Tanabe H, Nishino K, Nomura H, Kim JW, Kim BG, Pignata S, Alexandre J, Green J, Isonishi S, Terauchi F, Fujiwara K, Aoki D. Randomized Phase III Trial of 
Irinotecan Plus Cisplatin Compared With Paclitaxel Plus Carboplatin As First-Line Chemotherapy for Ovarian Clear Cell Carcinoma: JGOG3017/GCIG Trial. J Clin Oncol. 2016;34(24):2881-7. https://doi.org/10.1200/JC0.2016.66.9010.

4. Chiang YC, Chen CA, Chiang CJ, Hsu TH, Lin MC, You SL, Cheng WF, Lai MS. Trends in incidence and survival outcome of epithelial ovarian cancer: 30-year national population-based registry in Taiwan. J Gynecol Oncol. 2013;24(4):342-51. https://doi.org/10.3802/jgo.2013.24.4.342.

5. Annual report on Japanese ovarian cancer. Japanese gynecologic cancer committee. Acta Obstet Gynaecol Jpn. 2012;64:1029-41.

6. Liu SC, Ou YC, Wu CH, Fu HC, Tsai CC, Changchien CC, Lin H. Differences in tumor behavior between serous and non-serous ovarian carcinoma, focus on distribution of stage, laterality and survival. Eur J Gynaecol Oncol. 2019;40(5): 734-38. https://doi.org/ 10.12892/ejgo4597.201.

7. Liu H, Xu Y, Ji J, Dong R, Qiu H, Dai X. Prognosis of ovarian clear cell cancer compared with other epithelial cancer types: A population-based analysis. Oncol Lett. 2020;19(3):1947-57. https://doi.org/10.3892/ol.2020.11252.

8. Ku FC, Wu RC, Yang LY, Tang YH, Chang WY, Yang JE, Wang CC, Jung SM, Lin CT, Chang TC, Chao A, Lai $\mathrm{CH}$. Clear cell carcinomas of the ovary have poorer outcomes compared with serous carcinomas: Results from a single-center Taiwanese study. J Formos Med Assoc. 2018;117(2):117-25. https://doi.org/10.1016/j.jfma.2017.03.007.

9. Hsieh SF, Lau HY, Wu HH, Hsu HC, Twu NF, Cheng WF. Prognostic Factors of Early Stage Epithelial Ovarian Carcinoma. Int J Environ Res Public Health. 2019;16(4):637. https://doi.org/10.3390/ijerph16040637.

10. Blanco LZ Jr, Kuhn E, Morrison JC, Bahadirli-Talbott A, Smith-Sehdev A, Kurman RJ. Steroid hormone synthesis by the ovarian stroma surrounding epithelial ovarian tumors: a potential mechanism in ovarian tumorigenesis. Mod Pathol. 2017;30(4):563-76. https://doi.org/10.1038/modpathol.2016.219.

11. Gwinn ML, Lee NC, Rhodes PH, Layde PM, Rubin GL. Pregnancy, breast feeding, and oral contraceptives and the risk of epithelial ovarian cancer. J Clin Epidemiol. 1990;43(6):559-68. https://doi.org/10.1016/0895-4356(90)90160-q.

12. Sieh W, Köbel M, Longacre TA, Bowtell DD, deFazio A, Goodman MT, Høgdall E, Deen S, Wentzensen N, Moysich KB, Brenton JD, Clarke BA, Menon U, Gilks CB, Kim A, Madore J, Fereday S, George J, Galletta L, Lurie G, Wilkens LR, Carney ME, Thompson PJ, Matsuno RK, Kjær SK, Jensen A, Høgdall C, Kalli KR, Fridley BL, Keeney GL, Vierkant RA, Cunningham JM, Brinton LA, Yang HP, Sherman ME, García-Closas M, Lissowska J, Odunsi K, Morrison C, Lele S, Bshara W, Sucheston L, Jimenez-Linan M, Driver K, Alsop J, Mack M, McGuire V, Rothstein JH, Rosen BP, Bernardini MQ, Mackay H, Oza A, Wozniak EL, Benjamin E, Gentry-Maharaj A, Gayther SA, Tinker AV, Prentice LM, Chow C, Anglesio MS, Johnatty SE, Chenevix-Trench G, Whittemore AS, Pharoah PD, Goode EL, Huntsman DG, Ramus SJ. Hormone-receptor expression and ovarian cancer survival: an Ovarian Tumor Tissue Analysis 
consortium study. Lancet Oncol. 2013;14(9):853-62. https://doi.org/10.1016/S14702045(13)70253-5.

13. Luo H, Li S, Zhao M, Sheng B, Zhu H, Zhu X. Prognostic value of progesterone receptor expression in ovarian cancer: a meta-analysis. Oncotarget. 2017;8(22):36845-56.

https://doi.org/10.18632/oncotarget.15982.

14. Del Carmen MG, Smith Sehdev AE, Fader AN, Zahurak ML, Richardson M, Fruehauf JP, Montz FJ, Bristow RE. Endometriosis-associated ovarian carcinoma: differential expression of vascular endothelial growth factor and estrogen/progesterone receptors. Cancer. 2003;98(8):1658-63. https://doi.org/10.1002/cncr.11714.

15. Akahane T, Sekizawa A, Okuda T, Kushima M, Saito H, Okai T. Disappearance of steroid hormone dependency during malignant transformation of ovarian clear cell cancer. Int J Gynecol Pathol. 2005;24(4):369-76. 10.1097/01.pgp.0000165173.90339.a2.

16. Anglesio MS, Wiegand KC, Melnyk N, Chow C, Salamanca C, Prentice LM, Senz J, Yang W, Spillman MA, Cochrane DR, Shumansky K, Shah SP, Kalloger SE, Huntsman DG. Type-specific cell line models for type-specific ovarian cancer research. PLoS One. 2013;8(9):e72162. https://doi.org/10.1371/journal.pone.0072162.

17. DeLair D, Oliva E, Köbel M, Macias A, Gilks CB, Soslow RA. Morphologic spectrum of immunohistochemically characterized clear cell carcinoma of the ovary: a study of 155 cases. Am J Surg Pathol. 2011;35(1):36-44. https://doi.org/10.1097/PAS.0b013e3181ff400e.

18. Nolan LP, Heatley MK. The value of immunocytochemistry in distinguishing between clear cell carcinoma of the kidney and ovary. Int J Gynecol Pathol. 2001;20(2):155-9. https://doi.org/10.1097/00004347-200104000-00007.

19. Ju B, Wang J, Yang B, Sun L, Guo Y, Hao Q, Wu J. Morphologic and Immunohistochemical Study of Clear Cell Carcinoma of the Uterine Endometrium and Cervix in Comparison to Ovarian Clear Cell Carcinoma. Int J Gynecol Pathol. 2018;37(4):388-96. https://doi.org/10.1097/PGP.0000000000000430.

20. Zannoni GF, Morassi F, Prisco MG, De Stefano I, Vellone VG, Arena V, Scambia G, Gallo D. Clinicopathologic and immunohistochemical features of ovarian clear cell carcinomas in comparison with type I and type II tumors. Int J Gynecol Pathol. 2012;31(6):507-16. https://doi.org/10.1097/PGP.0b013e3182518557.

21. Shen F, Zhang X, Zhang Y, Ding J, Chen Q. Hormone receptors expression in ovarian cancer taking into account menopausal status: a retrospective study in Chinese population. Oncotarget. 2017;8(48):84019-27. https://doi.org/10.18632/oncotarget.20251.

22. Shafrir AL, Rice MS, Gupta M, Terry KL, Rosner BA, Tamimi RM, Hecht JL, Tworoger SS. The association between reproductive and hormonal factors and ovarian cancer by estrogen- $a$ and progesterone receptor status. Gynecol Oncol. 2016;143(3):628-35. https://doi.org/10.1016/j.ygyno.2016.09.024. 
23. Mote PA, Johnston JF, Manninen T, Tuohimaa P, Clarke CL. Detection of progesterone receptor forms A and B by immunohistochemical analysis. J Clin Pathol. 2001;54(8):624-30. https://doi.org/10.1136/jcp.54.8.624.

24. Rojas PA, May M, Sequeira GR, Elia A, Alvarez M, Martínez P, Gonzalez P, Hewitt S, He X, Perou CM, Molinolo A, Gibbons L, Abba MC, Gass H, Lanari C. Progesterone Receptor Isoform Ratio: A breast cancer prognostic and predictive factor for antiprogestin responsiveness. J Natl Cancer Inst. 2017;109(7):djw317. https://doi.org/10.1093/jnci/djw317.

25. Miyamoto $T$, Watanabe J, Hata $H$, Jobo $T$, Kawaguchi M, Hattori M, Saito M, Kuramoto $H$. Significance of progesterone receptor-A and -B expressions in endometrial adenocarcinoma. $\mathrm{J}$ Steroid Biochem Mol Biol. 2004;92(3):111-8. https://doi.org/10.1016/j.jsbmb.2004.07.007.

26. Peluso JJ, Liu X, Saunders MM, Claffey KP, Phoenix K. Regulation of ovarian cancer cell viability and sensitivity to cisplatin by progesterone receptor membrane component-1. J Clin Endocrinol Metab. 2008;93(5):1592-9. https://doi.org/10.1210/jc.2007-2771.

27. Peluso JJ, Gawkowska A, Liu X, Shioda T, Pru JK. Progesterone receptor membrane component-1 regulates the development and Cisplatin sensitivity of human ovarian tumors in athymic nude mice. Endocrinology. 2009;150(11):4846-54. https://doi.org/10.1210/en.2009-0730.

28. Friel AM, Zhang L, Pru CA, Clark NC, McCallum ML, Blok LJ, Shioda T, Peluso JJ, Rueda BR, Pru JK. Progesterone receptor membrane component 1 deficiency attenuates growth while promoting chemosensitivity of human endometrial xenograft tumors. Cancer Lett. 2015;356(2 Pt B):434-42. https://doi.org/10.1016/j.canlet.2014.09.036.

29. Willis BC, Sloan EA, Atkins KA, Stoler MH, Mills AM. Mismatch repair status and PD-L1 expression in clear cell carcinomas of the ovary and endometrium. Mod Pathol. 2017;30(11):1622-32. https://doi.org/10.1038/modpathol.2017.67.

30. Zhu J, Wen H, Bi R, Wu Y, Wu X. Prognostic value of programmed death-ligand 1 (PD-L1) expression in ovarian clear cell carcinoma. J Gynecol Oncol. 2017;28(6):e77. https://doi.org/10.3802/jgo.2017.28.e77.

31. Matulonis UA, Shapira-Frommer R, Santin AD, Lisyanskaya AS, Pignata S, Vergote I, Raspagliesi F, Sonke GS, Birrer M, Provencher DM, Sehouli J, Colombo N, González-Martín A, Oaknin A, Ottevanger PB, Rudaitis V, Katchar K, Wu H, Keefe S, Ruman J, Ledermann JA. Antitumor activity and safety of pembrolizumab in patients with advanced recurrent ovarian cancer: results from the phase II KEYNOTE-100 study. Ann Oncol. 2019;30(7):1080-7. https://doi.org/10.1093/annonc/mdz135.

32. Nishio S, Matsumoto K, Takehara K, Kawamura N, Hasegawa K, Takeshima N, Aoki D, Kamiura S, Arakawa A, Kondo E, Hirakawa T, Yamamoto K, Aoki M, Stein K, Keefe S, Fujiwara K, Ushijima K. Pembrolizumab monotherapy in Japanese patients with advanced ovarian cancer: Subgroup analysis from the KEYNOTE-100. Cancer Sci. 2020;111(4):1324-32. https://doi.org/10.1111/cas.14340.

\section{Figures}



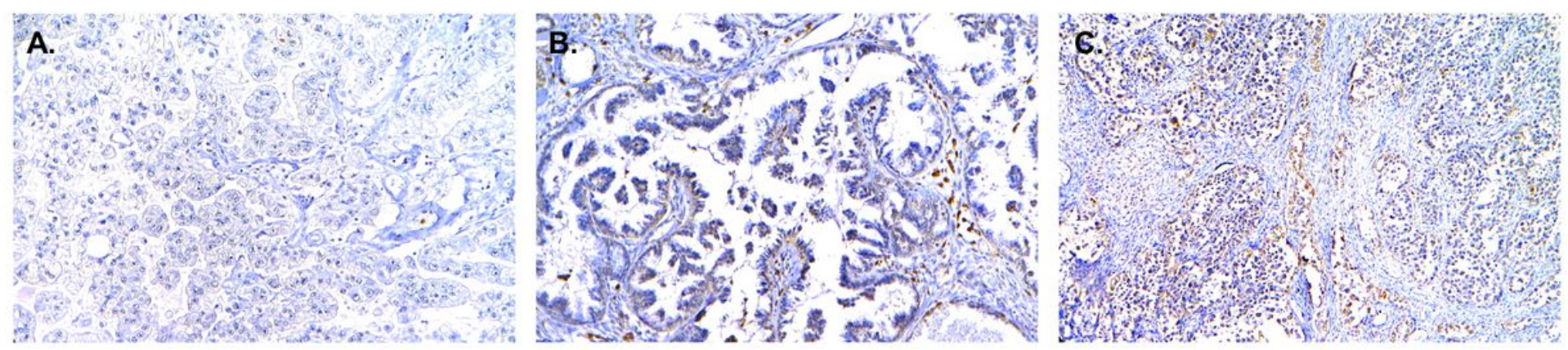

Figure 1

Representative cases of immunohistochemical staining for PR protein in ovarian clear cell carcinoma. (A) Negative expression. (B) Weak expression in $15 \%$ of the tumor cells with an H-score of 15. (C) Moderate expression in $40 \%$ of the tumor cells with an $\mathrm{H}$-score of 80 . 


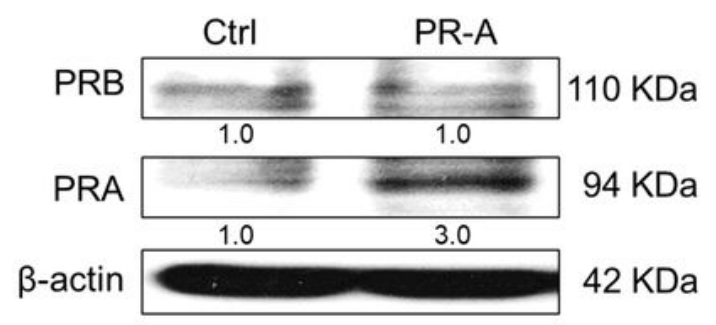

$24 \mathrm{H}$
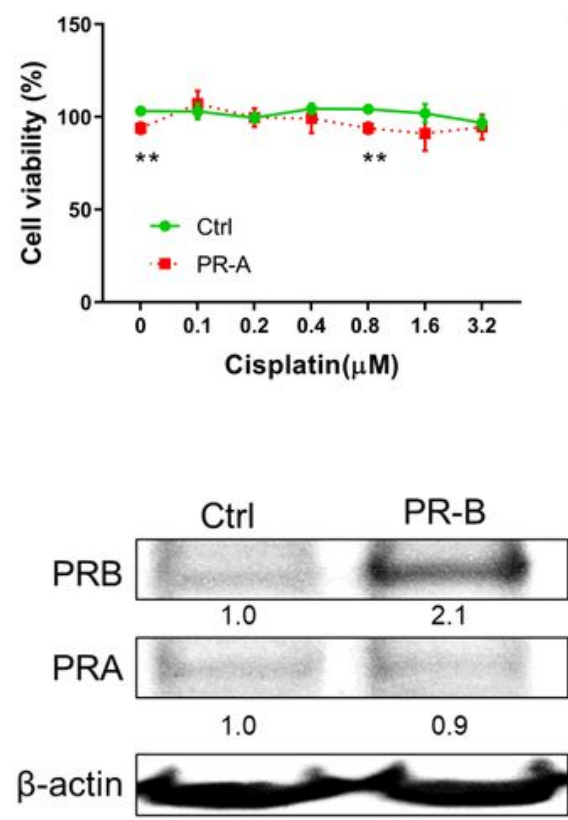

$24 \mathrm{H}$

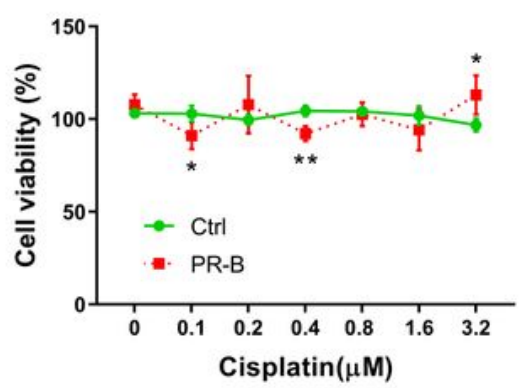

$48 \mathrm{H}$

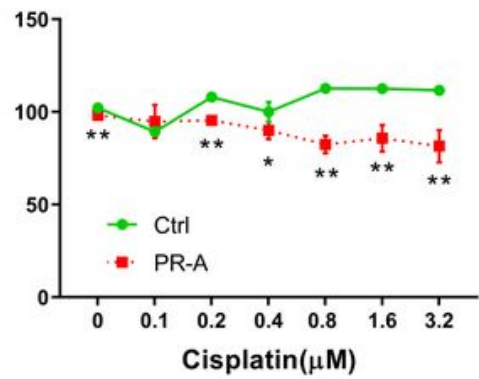

$110 \mathrm{KDa}$

$94 \mathrm{KDa}$

$42 \mathrm{KDa}$
$72 \mathrm{H}$

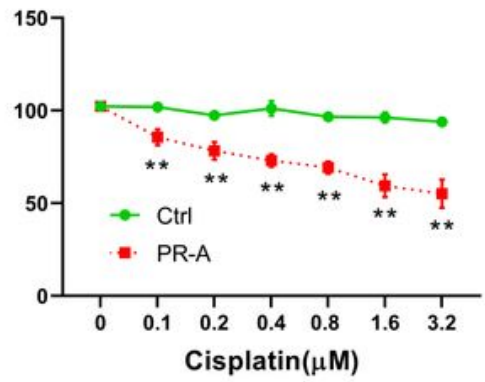

$48 \mathrm{H}$

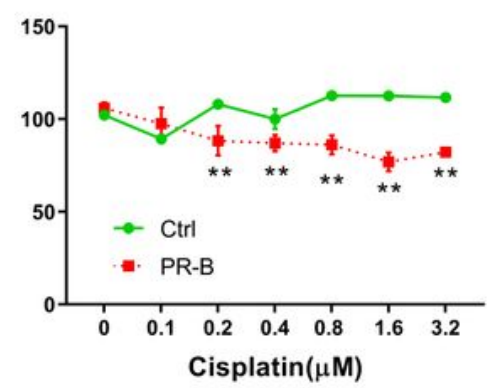

$72 \mathrm{H}$

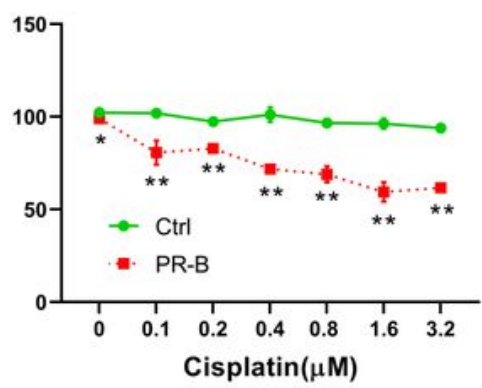

\section{Figure 2}

Western blot analysis of PR protein and comparison of cisplatin cytotoxicity in PR-overexpressed TOV$21 \mathrm{G}$ cancer cell lines. Experiments were performed in triplicate. Data was expressed as mean \pm SD of triplicate experiments. Control cells (green dotted line) were compared with PR-expressing cells (blue and red lines). ${ }^{*} p<0.05 ;{ }^{*} p<0.01$. (A) Western blot analysis of PR-A protein levels and cisplatin cytotoxicity in 
PR-A overexpressed TOV-21G cancer cell lines. (B) Western blot analysis of PR-B protein levels and cell viability assay in PR-B overexpressed TOV-21G cancer cell lines. 